PROBLEMS OF FORM 



\section{WRITINGSCIENCE}

EDITORS Timothy Lenoir and Hans Ulrich Gumbrecht 
Contributors

Dirk Baecker

Giancarlo Corsi

Elena Esposito

Michael Hutter

Klaus P. Japp

Niklas Luhmann

David Roberts

Karl Eberhard Schorr

Fritz B. Simon

Rudolf Stichweh

Helmut Willke 


\title{
PROBLEMS OF FORM
}

\author{
Edited by \\ DIRK BAECKER
}

Translated by

MICHAEL IRMSCHER, with LEAH EDWARDS

STANFORD UNIVERSITY PRESS

STA NFORD, C A L IF ORNIA

I 999 
Stanford University Press

Stanford, California

(C) 1999 by the Board of Trustees of the Leland Stanford Junior University

Printed in the United States of America

CIP data appear at the end of the book 